\title{
Hoezo kan een verdachte psychiatrisch onderzoek weigeren?*
}

\author{
Joke Harte
}

In juni 2009 steekt de 21-jarige Rex van P., bewoner van een opvanghuis voor daklozen in Amsterdam, drie medewerksters neer. Eén van hen overlijdt, twee anderen raken zwaargewond. Uit zijn verklaringen blijkt dat Van P. bang was dat hij vanwege agressief gedrag uit het opvanghuis zou worden gezet. Omdat Van P. vervolgens niet meewerkt aan een onderzoek door gedragsdeskundigen naar zijn geestvermogens, stelt de rechtbank dat niet kan worden aangenomen dat Van P. handelde vanuit een psychische stoornis. De rechtbank legt 16 jaar gevangenisstraf op, maar geen tbs. ${ }^{1}$ Tijdens het hoger beroep oordeelt het hof echter dat Van P. wel degelijk lijdt aan een psychische stoornis. ${ }^{2}$ Het hof baseert zich op de verslagen en verklaringen van de gedragsdeskundigen die de opdracht hadden Van P. te onderzoeken, maar door zijn weigerende houding geen diagnose konden stellen of een oordeel over de mate van toerekeningsvatbaarheid konden geven. Ook het feit dat er voor het incident pogingen werden ondernomen om Van P. in psychiatrische behandeling te krijgen, wordt in de onderbouwing meegenomen. Het hof veroordeelt Van P. tot 12 jaar gevangenisstraf en tbs met verpleging.

De zaak van Van P. laat zien dat de zogenoemde weigerproblematiek niet nieuw is binnen het strafrecht. Dit valt ook af te leiden uit het onderzoek van senior rechter Jongeneel, waarin hij vijftig rechterlijke uitspraken van zaken beschrijft waarin de verdachte medewerking aan het gedragskundige onderzoek had geweigerd; in 29 zaken werd overigens ondanks de weigering de maatregel tbs opgelegd. ${ }^{3} \mathrm{Al}$ decennialang proberen verdachten van ernstige strafbare feiten het gedragsdeskundig onderzoek te frustreren om te voorkomen dat zij de maatregel tbs opgelegd krijgen. Menig verdachte verkiest een lange gevangenisstraf boven de maatregel tbs, waarvan de duur niet alleen lang maar ook ongewis is. En naarmate de rechter minder informatie heeft over de geestesgesteldheid van de verdachte, wordt het lastiger om de aanwezigheid van een stoornis te onderbouwen en wordt de kans om een tbs-maatregel opgelegd te krijgen kleiner.

Afgelopen najaar kwam de zogenoemde weigerproblematiek volop in het nieuws. Michael P., verdachte van de moord en verdwijning van een jonge vrouw, bleek

* $\quad$ Prof. Joke Harte is hoogleraar bij de afdeling Strafrecht en Criminologie van de Vrije Universiteit en lid van de redactie van PROCES.

1 ECLI:NL:RBAMS:2010:BM8472.

2 ECLI:NL:GHAMS:2012:BW8075.

3 www.advocatenblad.nl/2017/10/13/meewerken-aan-tbs-onderzoek-verkeerd-uitpakken/. 
eerder te zijn veroordeeld voor een zwaar zedendelict waarvan jonge meisjes het slachtoffer waren. In die zaak had hij de oplegging van de maatregel tbs weten te voorkomen door niet mee te werken aan het gedragskundige onderzoek. In de media wordt verontwaardigd en met groot onbegrip gereageerd: Hoezo mogen verdachten zelf bepalen of zij mee willen werken aan een psychiatrisch onderzoek? Er wordt gesteld dat rechters en gedragsdeskundigen te weinig doortastend of zelfs laks zijn. Een petitie waarin de politiek ter verantwoording wordt geroepen en een verandering van het rechtssysteem wordt geëist, wordt binnen een week 400.000 keer getekend.

In de berichtgeving wordt de indruk gewekt dat wanneer een verdachte zegt niet te zullen meewerken aan een gedragskundig onderzoek, de betrokkenen zich daarbij neerleggen. Dit is zeker niet het geval. Een gedragskundig onderzoek wordt vaak gestart zonder instemming van de verdachte. Zeker als het om een ernstig feit gaat, trekken de gedragsdeskundigen alles dat mag binnen de grenzen van hun beroepscode uit de kast om de rechter zo goed en volledig mogelijk te informeren over de persoon van de verdachte. Het spreekt voor zich dat zij hierin meer succesvol zijn naarmate een verdachte meer bereid is over zichzelf te vertellen, of verminderd in staat is om psychopathologie verborgen te houden.

Ondertussen wordt via de media in rap tempo de ene na de andere oplossing voor de weigerproblematiek gelanceerd. Tweede Kamerleden van de VVD en de PvdA willen dat de rechter na twee jaar detentie nog eens moet kunnen kijken of op basis van observaties in de gevangenis alsnog tbs opgelegd kan worden. Er zijn deskundigen die menen dat diagnostiek niet nodig is voor de oplegging van de maatregel tbs; hiertoe zou afname van een risicotaxatie-instrument voldoende zijn. Ook wordt een oproep gedaan aan advocaten om hun cliënten een minder negatief beeld voor te houden van de tbs-behandeling. Tbs-advocaten pleiten er op hun beurt voor om de politieke bemoeienis met de tbs te verkleinen en de door- en uitstroming van tbs-patiënten te bevorderen.

Het is onverteerbaar dat verdachten die een gevaar vormen voor de maatschappij vanwege een psychiatrische stoornis na detentie onbehandeld terugkeren in de maatschappij. Alle betrokkenen moeten zich inspannen voor een zo goed mogelijke aanpak. De weigerproblematiek is echter een ingewikkeld probleem en eenvoudige en snelle oplossingen zijn er niet. 